Review

\title{
Drought, Sustainability, and the Law
}

\author{
Robert W. Adler
}

S.J. Quinney College of Law, University of Utah, 332 South 1400 East, Salt Lake City, UT 84112-0730, USA; E-Mail: Adlerr@ law.utah.edu; Tel.: +1-801-581-3791; Fax: +1-801-581-6897.

Received: 28 May 2010; in revised form: 17 June 2010 / Accepted: 12 July 2010 /

Published: 15 July 2010

\begin{abstract}
Researchers and responsible officials have made considerable progress in recent years in efforts to anticipate, plan for, and respond to drought. Some of those efforts are beginning to shift from purely reactive, relief-oriented measures to programs designed to prevent or to mitigate drought impacts. Considerably less attention has been given to laws that may affect practices and policies that either increase or decrease drought vulnerability. Water law regimes, drought response and relief legislation, and laws governing broader but related issues of economic policy—especially agricultural policy—should be evaluated more comprehensively to enhance incentives for more "water sustainable" practices in agriculture and other sectors of the economy. Those changes will be increasingly important if current climate change models are correct in their prediction that many parts of the world can expect more frequent and more severe conditions of meteorological drought in the ensuing decades.
\end{abstract}

Keywords: agriculture; climate change; drought; global warming; law; sustainability; vulnerability

\section{Introduction}

Drought has plagued human societies for millennia, sometimes causing serious economic impacts and human suffering [1,2], and at its extreme leading to the collapse of entire civilizations $[3,4]$. The frequency and severity of drought has already been exacerbated in recent years by the growing mismatch between a skyrocketing human population with higher per capita water use and relatively fixed supplies of usable water [3]. Moreover, even under the most optimistic climate change scenarios, drought is likely to increase in frequency, impact, and geographic range [5-7]. 
Drought and sustainability are linked in several critical ways. Adequate supplies of sufficiently clean water are essential to healthy societies and economies. At the same time, sustainable communities are likely to be more resilient - or less vulnerable - to the effects of reduced water supplies. Indeed, because most generic definitions of drought focus on the relative balance between meteorological factors and human or environmental needs [8], enhanced sustainability is one logical strategy to offset predicted increases in drought severity and frequency. Water pricing structures are likely to change, and to affect supply and demand factors in the face of climate change [9], but a full discussion of the economics of drought is beyond the scope of this analysis.

Considerable work has been done on the physical and environmental aspects of drought, and on the history of drought and lessons that can be learned from those experiences. Most of that analysis, although extremely productive, has focused on drought definitions and characterization; monitoring and warning systems; planning and response; relief efforts; and impacts analysis [10]. More recently, the study of hazard analysis generally and drought management more specifically has turned to an assessment of the vulnerability of different regions and societies to drought and other risks [11-13].

Less attention has been paid to the relationship between drought and sustainability, and to the role of law in guiding those relationships. To the extent that there is any "law" governing society's response to drought, it has been almost entirely ad hoc and reactive, and often occurs at the local or regional levels, which can reduce the effectiveness of both prevention and response. This parallels non-legal aspects of drought planning and management, which researchers and government reports have criticized widely on similar grounds $[14,15]$. There has also been relatively little analysis of drought and the law, and little attention to the relationship between drought and sustainability.

This article begins by providing a sustainability perspective on the difficulty of defining drought. Although the problem of drought definition has been recognized as a technical problem, at a more fundamental level the level and nature of scarcity deemed appropriate to trigger relief efforts is related closely to sustainability policy. Next, by reference to some of the more notable droughts of the twentieth century, it identifies some of the key linkages between drought, vulnerability and sustainability. Finally, the article explores ways in which existing legal regimes address drought in a largely reactive way, fail to promote sustainable systems and practices that might help to mitigate or prevent drought impacts, and in some ways actually decrease sustainability and hence increase society's vulnerability to drought. Revised laws and policies should focus on providing incentives to improve the efficiency of water use in drought-prone regions, or to shift water-intensive activities to regions that have adequate water supplies to support them. To be most effective, some of those laws and policies may have to shift from local or regional to national or even international design and implementation, although significant local or regional variability in physical and socio-economic conditions suggests that inter-regional flexibility is necessary as well.

\section{Discussion}

\subsection{Defining Drought: A Sustainability Perspective}

According to one review published a quarter century ago, there were more than 150 published definitions of drought in the academic literature, although the common theme is that drought results from some level of water shortage relative to human and environmental needs [16]. Because single 
indicators are usually insufficient to characterize the existence and severity of drought, a number of multi-factor drought indices have also been developed to delineate when droughts begin and end, and to characterize their severity [17,18]. Drought defies universal definition precisely because it is a relative concept that varies with location and with economic, social and political context. As one prominent drought expert noted, “...drought, like beauty, is largely defined by the beholder and how it may affect his or her activity or enterprise [8]".

From a purely physical perspective, adequacy of precipitation varies geographically [16]. Precipitation that would be abundant in an arid region might set record lows in a normally humid zone. Moreover, there is really no such thing as "normal" precipitation due to significant natural variation within any given climatic region. Given wide variations over time, however, even longstanding historic records may not fully characterize the climate within a given region $[3,16]$.

Choosing the correct measure of drought may also depend on the purposes of the definition. Because precipitation within a region generally is not subject to a normal probability distribution, the mean can vary significantly from the median $[16,18]$. A "percentage of average" approach defined by reference to the mean, therefore, can provide misleading results, for example, where "below average" reflects median precipitation within the selected time period. To avoid this problem, the Australian Drought Watch System uses a system of deciles, in which precipitation probability is divided into ten categories of probability based on the historic record [18].

Moreover, the amount or the percentage of seasonal or annual precipitation alone does not dictate the severity of a drought, because hydrologic impacts also depend on antecedent conditions. If an extremely dry year follows a long wet period in which a lot of water has been stored in the system (soil moisture, surface water levels, reservoir storage, etc.), physical impacts to natural or human water resources may be small. However, even a moderately dry year following a long period of incremental reductions in stored water can have more significant impacts. The hydrologic effects of drought are also affected by other environmental variables, such as temperature and humidity (which affect evapo-transpiration rates and plant water needs) and the nature and timing of precipitation (snow versus rain; or steady, moderate rains versus infrequent downpours) [16,18].

From an economic, social and political perspective, the severity and duration of drought also varies based on demand [16-18]. Regions with high water demand, such as agricultural areas that depend on large amounts of irrigation water, are likely to experience more serious impacts from a given level of shortage than areas whose water needs are more modest. Some of the factors that affect demand include population size and density; the nature and magnitude of water uses; natural or engineered infrastructure to store and convey water; and efficiency of water storage, use and conveyance.

To address these issues, researchers divide drought definitions conceptually into four broad categories [8,16]. Meteorological drought refers to deficiencies in precipitation relative to one of the norms suggested above (less than a defined amount per unit time, percent of average, etc.). Although reduced precipitation may or may not cause one or more of the impacts addressed in the other three categories, it is a necessary underlying cause when they do occur.

Hydrological drought refers to deficiencies of water storage and flow in natural or artificial systems, including reduced soil moisture, groundwater depth, stream flow, runoff volume, and water levels in lakes and reservoirs. The degree to which meteorological drought contributes to hydrological drought depends on preceding water conditions, amounts and patterns of use, and other factors. Meteorological 
drought necessarily precedes hydrological drought in time, and hydrological drought can persist long after meteorological conditions improve, especially where water storage in the system (such as groundwater or reservoir levels) requires a long time to recover.

Agricultural drought refers to deficiencies in soil moisture relative to crop or forage needs, leading to impacts such as reduced crop yield or quality, or total crop failures. As with hydrological drought, agricultural drought is preceded by meteorological drought, but is not an inevitable result; rather, it depends on prior conditions or responses, either natural or artificial in origin. For example, agricultural drought might not occur if a preceding period of wet weather caused significant storage of moisture in the soil, or if crop water needs declined due to cooler temperatures. Likewise, agricultural drought might be prevented if replacement or supplemental water can be brought from other sources.

Socioeconomic drought similarly refers to a deficiency in water relative to some economic need or resource, such as livestock watering, irrigation, hydroelectric power generation, or municipal and industrial use. Arguably, agricultural drought could be considered a subset of socioeconomic drought, but is distinguished by the direct physical relationship between meteorological and other related climatic conditions (such as temperature and humidity) and both soil moisture and plant needs.

Both agricultural drought and socioeconomic drought involve a variable balance between supply and demand. Demand, in turn, reflects both natural and artificial factors [19,20]. For example, agricultural demand for water can be reduced through the use of more efficient irrigation practices, drought tolerant crops or crop varieties, fallowing of marginal lands, and a focus on optimal profitability rather than maximum gross yield. Municipal demand can be reduced through a wide variety of mechanisms, from real cost and accelerating block pricing to financial incentives to mandatory regulations or rationing. Thus, water supplies that might seem luxurious to low-demand communities might be considered a severe socioeconomic drought in profligate ones. There is considerable debate, however, about the extent to which water should be viewed as a market, and the appropriate pricing structures to deal with scarcity $[9,19,21]$.

This review of the theory and status of drought definitions and indicators suggests important linkages between drought definitions and sustainability. Communities that support healthy economies with high levels of water efficiency will experience conditions of agricultural or socioeconomic drought less frequently, even under conditions of meteorological drought. Likewise, communities that can adapt their demand quickly before or during drought conditions will experience less severe social and economic impacts in the face of meteorological drought. In short, communities that are more "water sustainable" will be less vulnerable to drought impacts.

From a sustainability perspective, one also might add the concept of environmental drought to the two traditional effects-based concepts of drought (agricultural and socioeconomic). Healthy natural ecosystems are economic resources along with crops and processed food, and that provide valuable ecosystem services as well as intrinsic values. The balance between available water and ecosystem needs can either support or stress the health of those ecosystems and their individual components, as is true for more purely anthropocentric economic resources. As such, ecosystem needs might be considered as a subset of socioeconomic drought. Unlike socioeconomic drought, however, environmental drought depends on the inherent resilience of particular ecosystems to drought conditions. For example, species that evolved under frequent drought conditions will have developed adaptations that allow them to withstand those conditions. 
Human alteration of ecosystems, however, can change their inherent vulnerability to water stress. For example, if human water uses deplete stream flows to already marginal conditions, ecosystem impacts may occur under meteorological drought conditions that the system otherwise would be able to withstand. Declining groundwater levels due to unsustainable artificial pumping will increase the likelihood of drought-induced impacts to natural forests and other vegetation, where the combination of human and natural factors lowers groundwater below critical root zones. Ecosystem changes, in turn, can increase the vulnerability of human communities to drought. Where communities fill wetlands, increase impervious surfaces, or otherwise reduce the hydrologic storage capacity of a watershed, less water will be stored to buffer the effects of meteorological drought when it occurs, thus raising the probability of agricultural, hydrological, or socioeconomic drought. Sustainable environmental policies, therefore, can also reduce a region's vulnerability to drought.

Climate change will present several additional problems for the definition of drought, with additional implications for sustainability. Definitions of meteorological drought constructed by reference to historical records will no longer be accurate if climate change significantly changes precipitation patterns and probabilities, with some regions getting wetter and others getting significantly drier. In the face of those meteorological and hydrologic changes, we will clearly need to redefine our understanding of what is "normal" or "average" in various regions around the world. With respect to definitions of agricultural, hydrologic and socioeconomic drought, regions in which the magnitude and pattern of demand developed in light of past precipitation and other conditions will face increasing deficiencies in supply, to which those areas and economies have not had the need to adapt previously. Communities will be challenged to enhance their water sustainability in light of longstanding uses and levels of efficiency, and changes in water management are likely to represent extremely important modes of climate change adaptation [22].

\subsection{Drought and Sustainability: Lessons from Recent History}

An increased focus on sustainability could improve the ability of affected communities to anticipate, cope with, and even prevent drought impacts. Although there are many examples from earlier periods in history, two lessons from twentieth century droughts illustrate the main points well.

\subsubsection{The Great Plains, the Dust Bowl, and Beyond}

The Great Plains of North America has been vulnerable to a series of devastating boom and bust cycles, the latter of which usually coincided with periods of severe drought [23-29]. Although the "Dust Bowl" crisis of the Great Depression during the 1930s is the best known and perhaps most studied of these episodes, its roots date back to the period of intensive agricultural settlement during the last half of the nineteenth century and earlier drought-induced crises. And unfortunately, despite changes in practices and policies during and after the Dust Bowl, many of its lessons remain unheeded or forgotten, leading to the possibility of a future economic and environmental calamity in the region during inevitable future droughts.

Aided by U.S. government land polices designed to promote westward expansion, and further encouraged by railroad companies seeking new customers, speculators coveting quick profits from large-scale land purchases, and newspapers formed largely to promote those interests, settlers from the 
eastern United States flocked to the Great Plains in several waves during the late 1800s and early 1900s. Those migrants were lured by the promise of economic self-sufficiency, cheap and fertile land, and favorable weather. However, they brought farming practices and assumptions about weather rooted in Europe and the eastern United States that ultimately were not sustainable in the very different and highly variable climate of the Great Plains. Euro-centric views about farming and weather have led to similarly false assumptions in Australia, South Africa, and other regions in which Europeans introduced historical practices to regions with very different conditions [30].

Farmers and ranchers in the Great Plains fell victim to an early manifestation of the "hydro-illogical" cycle described by drought policy experts. As applied to modern drought management practices and policies, this cycle is characterized by panic and ad hoc, reactive approaches in the face of serious drought, followed by apathy and a return to past practices once the rains return. The back end of the cycle includes inadequate monitoring and foresight, sluggish realization when drought returns, and a repeat of the panic-driven, reactive approach once reality finally hits [14].

Great Plains settlers fell into a similar pattern in which they overstocked the range and overplanted crops to seek high profits during periods of favorable weather and high prices, leading to serious failures during periods of drought, excess summer heat, and sometimes freezing winters. That propensity was exacerbated during the early years of Great Plains settlement by the unscientific superstition that "rain follows the plow," and later by the false promise of weather modification. Even after those myths were dispelled, government policies and economic conditions encouraged boom cycles when commodity prices rose-in some cases fueled by war and other global events and export opportunities - and driven by advancements in agricultural technology such as the invention of the steel plow, the gasoline-driven tractor, and the combine. Even prior to the 1930s, unsustainable practices of overplanting marginal soils with extensive monocultures of cash crops, and overgrazing rangeland, led to periodic drought-induced collapses. Because the Great Plains economy was limited largely to agriculture, failing farmers and ranchers had few if any options for supplemental income, leading to loan defaults, foreclosures, and mass exoduses from the region. Those lessons were not heeded for long, however, and practices designed to promote maximum production at the expense of long-term sustainability returned with renewed precipitation and higher prices.

The ultimate example of these boom-busts cycle came during the Dust Bowl years of the Great Depression. The Dust Bowl provides a perfect lesson in the relationship between drought, vulnerability, and sustainability. The underlying physical cause of the Dust Bowl was the worst period of heat and drought to date in the measured meteorological record [25]. However, similar conditions of wind, drought, and heat had occurred previously, without the dramatic dust storms, soil erosion, and other catastrophic resulting environmental impacts. In the native prairies of the region, a dense and diverse flora of drought-resistant grasses stabilized the soil during periods of high winds, and the native species evolved to withstand periods of heat, cold, aridity and rain. Overgrazing denuded those grasses in natural rangelands, and mechanical plowing, cultivation and harvest exposed the underlying topsoil to the effects of heat, wind and drought. The shallow, dispersed root systems of crops planted in long, straight rows could not match the deeper, denser mats of continuous roots and vegetation of the native grasslands in their ability to protect the soil from sun, heat, desiccation and wind. Unsustainable 
agricultural practices thus rendered the region more vulnerable to natural, periodic, and predictable changes in the weather.

Likewise, the Dust Bowl saga highlights the relationship between unsustainable fiscal and economic policies and vulnerability to drought and other natural disasters. By optimistically planning only for the rich times, the farming and ranching community failed to maintain sufficient reserves of water, seed, forage and other inputs to sustain themselves during times of drought. Lured by easy access to credit and the assurance that land values and commodity prices would inevitably continue to rise, farmers and absentee owners saddled themselves with mortgages and large amounts of chattel debt to finance a new generation of efficient but very expensive equipment designed to support the new industrial farm economy. When crop prices declined dramatically, or when crop yields fell or failed altogether due to the drought and the dust storms, farmers had no reserves to cover their debt and no other resources such as seed grain or livestock feed to carry them through the protracted drought.

Given the environmental and economic collapse of the region's agricultural economy, land values inevitably plummeted as well, leaving insufficient equity to cover the loans, thus leading to farm failures and bankruptcies, foreclosures, and ultimately to bank failures. Even the supposedly more sophisticated finance community engaged in unsustainable practices by failing to maintain sufficient reserves of equity to withstand a significant downturn in the market in the event of drought or other setbacks, despite ample evidence of that risk from previous decades. Indeed, the causes and the effects of the Dust Bowl economic collapse are eerily similar to the home mortgage loan crisis of the early twenty-first century, in which lenders provided excess access to credit to aspiring homeowners with little or no financial reserve on the false assumption of perpetually rising property values.

The Great Plains states and the U.S. government responded to the Dust Bowl disaster with major changes in drought relief and agricultural policies designed both to provide compassionate assistance to families struggling with the mistakes of the past, and to change farming practices in ways designed to prevent similar effects in the future [23-27,29]. Conservation tillage, planting of windbreaks, retirement of marginal lands and their return to native grasses, and other conservation practices succeeded to some degree in improving the environmental sustainability of farming on the Great Plains. New programs and policies such as commodity price supports, bankruptcy relief, and crop insurance reduced the financial vulnerability of the affected communities to natural variables such as drought and to fluctuations in domestic and global agricultural markets.

Periodic drought has returned to the Great Plains since the 1930s, leading to renewed drought relief programs with several variations on the New Deal theme during the Eisenhower Administration of the 1950s, the Carter and Ford Administrations of the 1970s, and the Reagan Administration during the 1980s [15,31-33]. Although each of those droughts resulted in significant economic and other impacts on the U.S. farm community, neither the environmental nor the economic effects of drought in the second half of the twentieth century remotely approached those of the 1930s. At the same time, however, there are ominous warning signs that some of those very policies, along with changes in technology and agricultural practices similar to those that contributed to the Dust Bowl, could lead to environmental and economic problems that rival or exceed those that plagued the 1930s.

Indeed, some of the technological improvements that helped to boost agricultural productivity in the Great Plains after the Dust Bowl ended are likely to lead to even greater problems in the future. The 
severe water shortages that exacerbated impacts to agriculture during the 1930s have been addressed in two ways [34,35]. First, the federal government subsidized a large system of dams to store water for irrigation during times of low precipitation in the Great Plains. Second, widespread use of the centrifugal pump to power deep wells and center pivot irrigation systems allowed farmers to tap into a large pool of water in the High Plains aquifer. Great Plains farmers no longer need to rely entirely on precipitation to support millions of acres of wheat, corn, and other grains. Productivity has been increased further through hybrid crops, and through the use of nitrogen fertilizers, pesticides, and herbicides produced from fossil fuels [34,35].

This technologically assisted increase in productivity, however, is not likely to last indefinitely. Groundwater levels in the High Plains aquifer have plummeted [26,27,36-39]. Continued pumping at current rates is no longer sustainable both because of impacts on the resource itself, and because the deeper one pumps, the greater the cost both in dollars and in the resulting emissions of greenhouse gases necessary to generate electricity to power the pumps. Likewise, scientists predict that increasing temperatures due to global warming will boost populations of insects, parasites, and other crop pests that plague Great Plains monocultures [36]. Increasing levels of agricultural chemicals will be needed to sustain current farming practices and crop choices, with accompanying increases in environmental, economic and energy costs.

Finally, the system of U.S. agricultural support laws and policies developed first during the New Deal morphed during the supply side economic revolution of the 1980 s into one that promotes renewed over-production and unsustainable farming practices [34,35]. Those policies, boosted by massive federal subsidies to farmers to flood the world market with cheap commodity crops, now encourage U.S. farmers once again to plant "from fencerow to fencerow" despite plummeting commodity prices and significant resulting reductions in net farm income [40,41]. In the long run, absent a shift to more sustainable practices, those incentives will render farmers in the Great Plains more vulnerable to drought and other adverse conditions, just as they were in the late 1920s and early 1930s. Moreover, those same U.S. agricultural and trade policies simultaneously increase the vulnerability of farmers in developing countries, who can no longer compete with the flood of cheap commodities coming from the United States and, to a lesser extent, Europe [42]. The following comparison of recent droughts in the United States and in Africa during the 1980s and 1990s illustrates the importance of promoting more sustainable economies in the developing world to mitigate what are likely to be devastating consequences of inevitable future droughts.

\subsubsection{A Tale of Two Droughts}

A series of significant droughts began throughout the world in the early 1980s [16] and continued episodically throughout the decade. From a physical perspective, two of the most serious droughts struck the western United States and the Sahel region of Africa in the mid-late 1980s. Another severe drought hit the Horn of Africa around the turn of the century, and serious droughts continue in the American West and in Africa to this day. Although the meteorological severity of all of these events was similar, however, their socioeconomic effects differ significantly in ways that highlight the role of vulnerability and sustainability in dictating drought severity. While drought experts previously have provided useful comparisons of the effectiveness of drought policies in different developed countries [30], 
this analysis is designed to highlight the importance of increasing vulnerability in future drought policy, and the need to design more sustainable water policies to decrease that vulnerability in both developed and developing nations.

Drought blanketed the United States in 1988, ranging from California to the Pacific Northwest, the Northern Rockies, the Upper Midwest, and south to Georgia. But the effects of the drought were most pronounced in California and other western states, where it persisted through 1992 [32]. From a purely meteorological perspective, the California drought of the late 1980s and early 1990s was as severe as that of the late 1920s and early 1930s, and in some parts of the state was the worst in the twentieth century [43]. This protracted drought resulted in increased monetary and energy costs to pump and move water, lost hydro-electrical generation and higher costs to replace it (in both money and pollution); reduced agricultural income and increased costs to purchase livestock feed and other inputs; millions of dollars in losses due to depleted salmon stocks; declining waterfowl populations; increased forest fires and ensuing damage to property and natural resources; declining tourism and recreation, especially to the ski industry, diminished supplies to municipal users; and weakened natural ecosystems. Some estimates of gross agricultural losses exceeded a half a billion dollars, and increased ratepayer electric costs in the range of three billion dollars [43].

However, despite these significant and costly impacts, the late 1980s and early 1990s California drought did not result in the massive economic, social, and political dislocation and upheaval as did the droughts of the Great Depression years. It is useful to consider why, because some of those reasons suggest that paying attention to issues of sustainability will be critical to prevent or to mitigate the effects of even more serious future droughts around the world.

For one thing, the water resources infrastructure developed by the federal and state governments and the private sector since the early twentieth century buffered the region against the full effects of the drought [43]. Colorado River water stored in Lake Mead and Lake Powell during the rainy years of the early 1980s offset shortages from other sources in the southern parts of the state, and California's own system of more than 150 major reservoirs provided additional reserves during the early years of the drought. As a result, California farmers did not face reduced water deliveries for at least the first three years of the drought. Additional water stored in aquifers offset declining surface water supplies. Still, by the end of the drought, reserves of both surface water and groundwater had declined, meaning that more serious impacts might have occurred if the drought continued even longer, or if it had not followed such a wet period beforehand. California will not likely be able to "store its way" out of the more severe and protracted declines in precipitation, snowpack storage, and runoff expected due to climate change. Moreover, reservoirs and extensive related water diversions and conveyance systems themselves cause serious environmental impacts that reduce the sustainability of ecosystems and economic resources in other ways [44].

Second, because it has a sufficiently sophisticated set of legal and political institutions, California was able to reduce demand through efficiency improvements adopted, encouraged, or required by municipal and agricultural users, and to reallocate water among users through water banks and other market tools in ways that helped to mitigate the long-term impacts of the drought. Those programs and transactions have been criticized on numerous grounds as insufficient, inefficient, and not reflective of true markets $[21,43,45,46]$. There is little doubt, however, that the effects of the drought would have been worse absent those efforts. 
Third, unlike the Great Plains of the 1930s, the economies of California and other affected western states in the 1980s and 1990s were diverse and robust. Although some economic sectors incurred more harm than others, the economy of the state and the region as a whole was better able to withstand the effects of the drought because some sources of jobs and income are relatively less dependent on water than others, and because resulting tax and other revenues at both the federal and state levels could be invested in drought response and relief efforts. As one example, large southern California municipalities were able to pay farmers in the Imperial Valley to fallow land and to improve irrigation efficiency in ways that allowed more water to be conveyed to the thirsty, still thriving cities $[45,46]$. Viewed in light of the current California state fiscal crisis, however, the state's vulnerability to future drought might be considerably greater.

Fourth, the impact of the drought was buffered by the size, diversity, flexibility, and economic strength of the United States as a whole. Even within California, if the market functions properly, gross income from declining yields can be offset in part by increased crop prices due to declining supplies [43]. Moreover, given the national or international scope of agricultural markets, and the absence of trade barriers and the presence of functional markets within the country, declines in crop yields in one region can be offset by increased production elsewhere, and that in fact happened during the late 1980s and early 1990s drought [47].

Of course, those shifts in regional production cause distributive changes in farm income. However, given that drought strikes different agricultural areas over longer periods of time, temporary distributive effects can even out over time, with each region gaining or losing relative market share during different periods. Moreover, if the locus of agricultural production shifts in the face of regional drought, a country as a whole will not face the kinds of food shortages and resulting malnutrition faced in other parts of the world. The ability of farmers within a drought-stricken region to withstand temporary shifts in production and income, however, depends on their overall economic condition and cash and other reserves, or the existence of government risk allocation programs (through price supports, crop insurance, or otherwise) to carry them through the crisis. In California, the agricultural sector was easily strong enough to bear the impacts of the drought [43].

In short, the California drought of the late 1980s and early 1990s, like many droughts in various parts of the United States since the 1930s, did not have nearly the same level of economic and social impacts as the Dust Bowl disaster. Steps taken both by the government and by the private sectors, whether or not designed to deal with drought risk per se, significantly reduced the country's vulnerability to drought. Absent increased attention to the sustainability of U.S. agricultural practices, water use and management policies, and other factors, however, the United States may be more vulnerable to droughts of increased frequency and severity expected in the coming decades as a result of climate change. A hint of those potential impacts can be gained by comparing the recent drought experience of California and other western states with those of selected African nations during the same general time period. The same comparison suggests what steps might be taken to use sustainability as a larger strategy to reduce drought vulnerability in those and other parts of the world.

Large portions of Africa historically have been prone to serious drought. In Ethiopia, historical records document drought and resulting famine in the ninth, thirteenth, fourteenth, and seventeenth through twentieth centuries [48]. In the mid-1980s, drought left eight million people in need of emergency food relief, including $15.6 \%$ of all children under the age of four and more than a quarter of 
all children between five and fourteen. Drought in Ethiopia is exacerbated by unsustainable environmental conditions similar to those that contributed to the Dust Bowl in the United States, such as historical soil erosion, deforestation, and other past practices that have eroded the country's natural resource base. As might be expected, however, Ethiopia was far more vulnerable to the effects of drought than the United States or other developed nations for several additional reasons, including external wars with Somalia and other nations, internal civil conflict, a history of feudal economic and political institutions, and widespread poverty.

Kenya is similarly subject to cyclic droughts, but major droughts that once recurred roughly once a decade have increased in frequency in recent years. Researchers documented twenty-three droughts in Kenya between 1883 and 2000, varying in duration, geographic reach and impacts, but four of which were identified as "nationwide" [49]. In the late 1990s, Kenya experienced a virtually nationwide, severe drought, as did and portions of six surrounding African nations (Djibouti, Eritrea, Ethiopia, Somalia, Sudan, and Uganda). Rainfall was less than forty percent of normal, even in areas of typically high precipitation. Ground water levels dropped, the mean discharge of many streams dropped by sixty percent, and some perennial rivers dried up entirely. Environmental effects included land degradation, desertification, and loss of biodiversity. Reservoir storage plummeted, and some nearly dried up entirely, affecting both water supply and hydroelectric power generation. Because seventy percent of Kenya's electricity was produced through hydroelectric generators at the time, it was particularly vulnerable to those impacts.

The human impacts of those shortages were also severe. About three quarters of Kenya's farmers were threatened by malnutrition and starvation, and nearly five million people were dependent on food aid (16\% of Kenya's population). Large numbers of livestock and wildlife died due to heat and lack of water. In Nairobi, residents went without water for three weeks, waited in long lines for water from a few sources, and unscrupulous private water dealers sold water at extortionist prices. Rural residents often had to walk from three to twenty kilometers to find water. Unlike California, in which a strong economy was able to buffer the effects of the drought, Kenya's entire economy declined. Gross domestic product plummeted, inflation rose dramatically, and the country's exchange rate fell to an all time low. Social disruption and dislocation was high as well, as many pastoralists lacked any source of replacement income, abandoned their livelihoods, and either became dependent on food aid or moved to urban areas in search of work. Many children dropped out of school because families could not longer afford the fees, or to help supplement family income.

A report prepared cooperatively by the United Nations Environment Programme and the Kenyan Government identified a number of additional ways in which unsustainable practices and economies increase vulnerability to drought [49]. For example, just as U.S. price supports and crop insurance can encourage the very unsustainable practices that contribute to future drought impacts, food relief in Africa creates the risk of dependency, in which people in some regions simply stop growing food and depend entirely on relief instead. While California had at least some options to shift scarce water among regions and uses, Kenya faces chronic water shortages all the time, with a growing population and fixed or diminishing water resources bringing it close to the lower limits of acceptable per capita supplies. River flows were declining even before the drought struck, potentially due to deforestation and cultivation of steep, erosive slopes, or to increased withdrawals for irrigation and other uses. Many small storage dams and natural pans are filled or partially filled with silt, resulting in far less capacity 
to store water from wet years as a buffer against ensuing droughts. Moreover, because farmers in previously humid areas of the country were not used to planning for drought, they only stored enough seed and other resources to reach the next harvest.

Not surprisingly, the 2000 U.N. and Kenyan Government report proposed at least some ways to shift from purely reactive forms of drought relief to preventive strategies designed to enhance sustainability and to decrease drought vulnerability as a result. Those included a shift to demand-based, comprehensive river basin land use and water planning and management that assumes cyclic and increasingly frequent droughts as part of the norm rather than an aberration; efforts to promote traditional, community-based means of water management and allocation; programs to de-silt small storage reservoirs and pans to enhance storage, using local labor in return for water provided from those sources; increased diversity of renewable energy sources, such as geothermal energy; a shift to sustainable agricultural practices designed to promote self-reliant communities; and an end to food relief programs not tied to measures to improve sustainable livelihoods.

Those proposals, however, clearly are easier to make than to accomplish. At the close of the first decade of the twenty-first century, the Horn of Africa is once again plagued by serious drought. In the intervening two decades, very little was done to improve sustainability in ways that would be effective in mitigating drought. Because serious droughts that previously occurred only once a decade now recur every two to three years, the country is in an "almost continuous state of disaster management, relief and rehabilitation. The next disaster occurs before attention can shift to mitigation and preparedness." Meaningful response to the 2006 drought in Kenya, for example, came only after the situation had become acute, by which time eleven million people needed food, malnutrition had exceeded emergency thresholds, and over seventy percent of livestock had died in some locations [50].

\subsection{Drought, Sustainability and the Law}

Improved laws and legal institutions might increase the focus on sustainable water use in ways that would help to forge a more proactive, prevention-oriented approach to drought. To the extent that they exist at all, current legal regimes address drought in a largely reactive way, fail to promote sustainable systems and practices that might help to mitigate or prevent drought impacts, and in some very important ways actually decrease sustainability and hence increase vulnerability to drought. Based on the themes described above, the following is a preliminary effort to scope out the major ways in which existing legal systems are insufficient to deal with drought, and in particular, to do so from the perspective of sustainability. Revised policies should ensure that drought risk is properly taken into account in key economic decisions, and that activities properly account for hydrological realities.

Of course, at both the domestic and international levels, arguably the entire body of water law focuses on drought by establishing rules for the use and allocation of water as a potentially scarce resource. Elsewhere, however, I explain how the major doctrines of U.S. water law (some of which were derived primarily from earlier doctrines in England and elsewhere) are ill-suited to the increasing problems of scarcity that are likely in the wake of climate change, and that a major shift in water resource law and policy will be needed to do so [51]. The system of riparian rights prevalent in the eastern United States-based on common law principles that developed in the usually humid British Isles at a time when water resource conflicts were infrequent-generally assumes abundant 
supplies that can be divided equitably among competing users. The doctrine of prior appropriation that prevails in the arid West is designed more specifically to choose "winners" and "losers" when water supplies run low. However, because abundant storage and conveyance systems have buffered even arid western states from significant problems of scarcity thus far, that system has not yet been tested extensively in times of extreme drought.

For one thing, the law generally has not addressed in any systematic way the troubling question of drought definitions discussed earlier. As one example of the significant problems this inattention might cause, the U.S.-Mexico Treaty governing allocation of the Rio Grande and the Colorado River provides for modified water allocations in the event of "extraordinary drought." That term is not defined in the treaty, however, leading to looming disputes about when the provisions it triggers might occur [52]. If there was a standard scientific definition of drought by reference to which that term might be interpreted, the absence of a definition in the treaty itself might be more manageable. The fact that the term "drought" is subject to so many different physical, economic and social connotations, however, renders it an extremely malleable idea for purposes of legal interpretation. In the U.S.-Mexico treaty, the adjective "extraordinary" exacerbates that ambiguity.

Other examples in U.S. law highlight problems caused by ambiguous, conflicting, or nonexistent drought definitions. In response to serious droughts during the mid-1970s, for example, a federal interagency committee designated counties eligible for federal relief, absent any clear legal standard or even guidance regarding the appropriate definition of drought [53]. As a result, and presumably in the face of significant political pressure to provide relief liberally, two thirds of the counties in the Nation were designated as drought disaster areas, making them eligible for some forms of federal relief. That unguided approach likely resulted in undeserving recipients of aid, and spread available resources so thinly that those more seriously affected may not have received as much aid as they needed. At the same time, however, different federal agencies applied differing definitions of drought to identify eligible recipients. Although there might be legitimate reasons why different criteria are appropriate for different relief efforts, critics suggested that those differences were more ad hoc than well considered.

Those kinds of definitional problems are significant because they impede the effective operation of drought response and relief efforts. From the perspective of sustainability more broadly, however, it is even more troublesome that the basic definition of drought has not been given more serious legal attention. As discussed above, drought is a relative concept in two major respects. First, drought can be viewed as a shortage of precipitation or other measure of water resources (reservoir storage, etc.) relative to some concept of what is "normal." It is entirely "normal" for weather to vary over time according to some probability distribution of high and low precipitation and other conditions, however, thus distinguishing weather from climate and characterizing the climate of a region. There is no scientifically or presumptively "correct" definition of what portion of the low end of that probability distribution constitutes drought. This suggests that the definition of drought should be determined based on considered societal policy decisions about how the risk of water shortages should be distributed. Risk allocation is one traditional function of the law. Second, drought defines water shortage relative to human and environmental needs. As shown above, the magnitude and distribution of those needs, and societal vulnerability to shortages, all can be affected by the sustainability of 
various policies and practices. A second role of law is to promote or require behavioral changes - at the individual and societal levels - deemed beneficial to the community [54].

Prevailing water law regimes, at least in the United States, do not fully integrate the concept of drought into the main body of rules governing water rights and allocations. In many state water law systems, drought is not addressed at all as a distinct concept. There are some notable recent exceptions in the water law of some U.S. states, in which various water rights and obligations can be modified in the event of drought [55,56]. However, even under those provisions drought is treated as an exceptional circumstance determined on an ad hoc, discretionary and emergency basis, for example, through an emergency drought declaration issued by the state governor. All water law regimes, of course, are designed to allocate the resource in times of both plenty and shortage. Typically, however, they do so according to the same rules-whether scarcity results from meteorological drought or due to population growth, inefficient water use, inadequate water resources infrastructure, or other artificial factors that may lead to an imbalance between supply and demand. As a result, the "winners" under the prevailing legal regimes have little or no incentive to take steps to improve water use sustainability in ways that might prevent or mitigate drought impacts, such as improving their efficiency under all conditions, or curtailing uses proportionate to a drought.

In prior appropriation states, holders of senior water rights-defined entirely by reference to temporal priority rather than broader societal decisions about the value of competing uses-receive their full allocations before junior appropriators receive any water at all. Any reallocation of water rights to more important or more efficient uses is left largely to the market, which operates inefficiently at best due to various impediments to functional markets under that system of law. Where statutory or other preferences exist, the allocation of scarce water reflects more politically accountable decisions, but those statutory "winners" still have little incentive to conserve or to engage in other sustainable practices, at least until resources become so scarce that they, too, face supply shortages. In theory, the prior appropriation system incorporates a prohibition against waste (inefficiency), and limits water rights to "beneficial use," defined in part by reference to the amount of water reasonably necessary to support the intended use. In practice, however, those tenets of prior appropriation law have been enforced weakly at best [57].

Pure riparian rights systems, in theory, allocate scarce water among competing users according to a variety of equitable factors, thus requiring everyone to share in the risk of scarcity. Even under common law administration of riparian rights, however, courts often established de facto preferences among users [58]. The uncertainty and instability inherent in such a case-by-case system of allocation, however, left large water users in those states with little incentive to engage in more sustainable practices than in prior appropriation states. Under more recent statutory and administrative systems of riparian rights (so-called "regulated riparianism"), statutory preferences operate much as they might in prior appropriation states, and with the same weak incentives for conservation. The administrative process, however, does provide at least the opportunity for the responsible agencies to impose efficiency requirements as a condition of water use permits.

So what happens when the main body of water law does not integrate the concept of drought as a separate constraint on water use and efficiency? One possibility, as I suggest elsewhere [51], is to increase the national role in water law and policy in ways that promote water sustainability and the transferability of either water - or the economies that rely on them-as the location of water supply 
shifts. Of course, given the high degree of variability in both physical and socio-economic conditions that affect or depend on water resources, broad-based national (in the United States, federal) policies require sufficient flexibility to address those differences, as well as unpredictably changing conditions [51,59].

Another option is simply to leave further adjustments to the market. Water users would then have to make risk decisions on the basis of the background legal regime that applied in their jurisdiction, and those whose rights or uses are disfavored would have an incentive to use whatever market mechanisms exist to reallocate water more efficiently. At least in theory, those who hold preferred rights would have an incentive to use water more efficiently so they would have more to convey (for a profit) during times of shortages. Those with junior or otherwise less preferred legal rights would have an equal or even greater incentive to conserve, to avoid unnecessary costs of purchasing rights when needed. Although not an optimal situation for the reasons discussed above, over time these incentives might prompt rational parties to engage in more sustainable water practices in advance, rather than waiting for a drought crisis to occur.

Until the 1930s, both the federal and state governments in the United States adopted a similar laissez faire approach to drought relief. Relief efforts were left to private, nongovernmental organizations, but for the most part, those who made ultimately unsound risk decisions that could not be remedied through the private market went bankrupt and moved on to other places in search of new livelihoods. Of course, at least since enactment of the Reclamation Act of 1902, the U.S. government has provided subsidized water for irrigation and other uses, but to promote development generally and not as a form of drought relief in particular.

As a society, however, since the Great Depression the United States and other nations have decided that this "sink or swim" approach to drought was not acceptable, and began to augment the system of risk allocation reflected in the main body of water law with entirely separate programs designed to provide emergency response and relief measures. Those measures have taken such forms as government funding or other assistance for supplemental water supply, subsidized feed or other agricultural inputs, subsidized crop insurance, and direct relief payments. Basic compassion for the unfortunate is one possible justification for this governmental intervention, which essentially reallocates risk (and wealth) to those whose lives and livelihoods are disrupted by factors perceived to be beyond their personal control (such as drought or other "natural" disasters, or unemployment caused by economic factors beyond the control of individual workers). That rationale, of course, underlies the much broader set of social support mechanisms begun in the United States mainly during the 1930s (such as social security and welfare), and adopted more widely by other countries around the world.

Several more strictly economic rationales also might justify governmental drought response and relief. When large numbers of farms or other businesses decline in profitability or fail altogether due to drought impacts, the secondary economic impacts to entire surrounding communities and economies can be significant. During the Dust Bowl, drought impacts extended far beyond the boundaries of the farm to the entire banking, real estate, and financial infrastructure of affected regions [23-27,29]. Drought relief programs, therefore, supported or rehabilitated entire regional economies, and not simply individual farmers. Moreover, farming, ranching and other businesses that rely heavily on variable precipitation or other uncertainties of weather involve a significant degree of 
risk. Because all business ventures involve risk, a laissez faire approach would dictate that agricultural entrepreneurs should be expected to internalize that risk just like any other business. But farmers arguably merit more societal support for two reasons. First, the kind of weather-related risk encountered by farmers is often less amenable to predictive analysis than are other forms of business risk. That rationale will strengthen given increasingly unpredictable precipitation and other weather conditions expected due to climate change. Second, to the extent that they produce some of the most basic, fundamental life support products on behalf of the rest of society, arguably farmers take those risks on behalf of society as a whole. Drought relief efforts allocate that risk across society in ways that allow farmers to continue to feed others.

Logical though those rationales may be, however, improperly designed governmental drought relief programs can inject a significant degree of distortion into the agricultural economy in ways that reduce or eliminate incentives to engage in sustainable farming practices in drought-prone regions. Just as providing unconditional food relief to drought-stricken individuals in Kenya arguably discourages self-sufficiency, providing unconditional drought relief or crop insurance to farmers regardless of the nature and wisdom of their farming choices relative to the region arguably eliminates incentives to engage in more water sustainable practices. Such practices might include planting drought-resistant crops or crop varieties, cultivating only in productive soils, using water-efficient tilling and irrigation methods, fallowing acreage during the worst droughts, and diversifying the farm economy rather than relying exclusively on monocultures of commodity crops that may be vulnerable to drought.

As noted earlier, during the early 1990s Australia decided that providing relief under what might be referred to as conditions of "normal" aridity in a given region encouraged unsustainable farming practices, and that relief should be provided only for conditions that a prudent farmer could not have reasonably predicted in the region. Drought legislation designed under that principle would require farmers and other water users to plan for the "normal" range of meteorological conditions in the region, rather than receiving relief whenever precipitation simply fell below "average" conditions for a requisite period of time, whether defined as a regional mean, median, or otherwise. Legislators or other decision makers would have to make tough decisions about what range-within the regional precipitation probability curve-should define extraordinary conditions beyond which prudent businesses should be expected to plan. If standards are set at the low end of the probability curve, relief will be provided less frequently to buffer the effects of dry weather, putting more farmers and other water users at risk. Such standards would maximize incentives to engage in water sustainable farming and other practices. If precipitation patterns shift as much as has been predicted due to climate change, however, making those decisions will become increasingly complex.

Moreover, thus far governments have tended to pass drought relief legislation on an ad hoc, purely reactive basis, rather than adopting comprehensive drought legislation like that proposed but not adopted by the U.S. Congress in 2003 [30]. As discussed earlier, drought management experts and government reports have universally criticized this practice as producing relief measures that are ineffective, poorly coordinated, and entirely short-term and reactive in focus. An ad hoc, emergency-oriented legislative practice can also be criticized, however, because it distorts whatever risk allocation principles and incentives for sustainability may be intended in existing water law regimes. When legislatures pass drought relief measures solely in response to individual crises, it is too late to adopt policies designed to require or to encourage farmers to engage in sound risk management 
and more sustainable practices. Rather, especially given the political pressures to help desperate constituents, emergency legislation adopted after drought has already struck inevitably focuses almost entirely on providing the necessary physical and financial relief. One possible solution would be to adopt legislation that embraces a comprehensive policy on drought prevention and management, and that promotes sustainable farming and other water use and management policies in advance of any specific crisis. This anticipatory approach can facilitate more objective decisions because it separates longer-term policy decisions from impacts to particular political constituents. Of course, the necessary corollary would be subsequent legislative discipline, i.e., legislators need to avoid the inclination to continue to bail out those who fail to respond to the incentives or requirements provided in the omnibus legislation.

An alternative approach to providing the necessary incentives for more sustainable water practices designed to reduce drought frequency and impacts would be to integrate matters of drought planning and policy directly into the main body of law governing water resources planning and allocation, rather than in separate legislation that operates independently from that law. In the United States, the disconnect between water law and drought relief policy is explained in part by prevailing notions of federalism, under which water law is dictated primarily by individual states, whereas the majority of drought relief has come from the federal government. (Similar disconnects may occur in other countries with a similarly bifurcated form of government.) Moreover, historically the U.S. federal government has been extremely reluctant to intrude directly on issues of individual state water law and management, as well as related issues of land use planning and regulation [51]. Ironically, however, the federal government ends up impinging on state water law indirectly through water subsidies, drought relief and other policies that distort the incentives inherent in state water law $[59,60]$. If federal drought relief and other policies change the economic dynamics of state water law anyway, it would be better to do so through direct, integrated approaches designed to promote more sustainable water uses and practices that help reduce society's vulnerability to drought.

From an even broader perspective, other laws and policies may have as much or even more influence on key decisions about sustainability that affect the frequency or severity of drought as laws related directly to either water use and allocation or drought planning, management and relief. For example, the huge body of U.S. law governing national agricultural policy, most notably the Farm Bill but also related legislation governing farm bankruptcies and tax and trade policies, are the primary drivers of decisions by small farmers and large agribusiness alike about what crops to grow, in what quantities and locations, and under what circumstances. Those decisions may have a far greater influence on vulnerability to drought than decisions about drought policy per se. Thus, a truly comprehensive legislative approach to enhancing water sustainability in ways that reduce society's vulnerability to drought also must re-evaluate and amend laws and policies that drive important underlying economic decisions by the agriculture industry and others.

\section{Conclusions}

Researchers and responsible officials have made considerable progress in recent years in efforts to anticipate, plan for, and respond to drought. Some of those efforts are beginning to shift from purely reactive, relief-oriented measures to programs designed to prevent or to mitigate drought impacts. 
Considerably less attention has been given to laws that may affect practices and policies that either increase or decrease drought vulnerability. Water law regimes, drought response and relief legislation, and laws governing broader but related issues of economic policy-especially agricultural policy-should be evaluated more comprehensively to enhance incentives for more "water sustainable" practices in agriculture and other sectors of the economy. Those changes will be increasingly important if current climate change models are correct in their prediction that many parts of the world can expect more frequent and more severe conditions of meteorological drought in the ensuing decades.

\section{Acknowledgements}

I would like to express my appreciation to Joel Mintz and John Dernbach for inviting this article and for organizing this issue devoted to sustainability and the law. Ariel Calmes (J.D. candidate, University of Utah, S.J. Quinney College of Law) provided excellent research assistance in support of this analysis.

\section{References and Notes}

1. Cooley, H. Floods and Droughts. In The World's Water 2006-2007, The Biennial Report on Freshwater Resources; Gleick, P.H., Ed.; Island Press: Washington, DC, USA, 2006; pp. 91-142.

2. Palmer, W.C. Meteorological Drought; U.S. Department of Commerce: Washington, DC, USA, 1965; U.S. Weather Bureau Research Paper No. 45.

3. Trenberth, K.; Overpeck, J.; Soloman, S. Exploring Drought and Its Implications for the Future. Eos 2004, 85, 27-29.

4. Climate and History, Studies in Past Climates and Their Impact on Man; Wigley, T.M.L., Ingram, M.J., Farmer, G., Eds.; Cambridge University Press: Cambridge, UK, 1981.

5. Climate Change 2009 Science Compendium; McMullen, C.P., Jabbour, J., Eds.; United Nations Environment Programme: Nairobi, Kenya, 2009; pp. 8-9, 38-40.

6. Wang, G. Agricultural Drought in a Future Climate: Results from Fifteen Global Climate Models Participating in the IPCC Fourth Assessment. Clim. Dynam. 2005, 25, 739-740.

7. Nicholls, N.; Coughan, M.J.; Monnik, K. The Challenge of Climate Prediction in Mitigating Drought Impacts. In Drought and Water Crisis: Science, Technology, and Management Issues; Wilhite, D.A., Ed.; Taylor \& Francis: Boca Raton, FL, USA, 2005; pp. 37-46.

8. Wilhite, D.A.; Buchanan-Smith, M. Drought as Hazard: Understanding the Natural and Social Context. In Drought and Water Crisis: Science, Technology, and Management Issues; Wilhite, D.A., Ed.; Taylor \& Francis: Boca Raton, FL, USA, 2005; p.4.

9. Roseta-Palma, C.; Monteiro, H. Pricing for Scarcity; Working Paper No. 2008/65; Centro de Estudos Sobre a Mudança Socioeconomic: Lisbon, Portugal, June 2008.

10. Drought and Water Crisis: Science, Technology, and Management Issues; Wilhite, D.A., Ed.; Taylor \& Francis: Boca Raton, FL, USA, 2005.

11. Blaikie, P.; Cannon, T.; Davis, I.; Wisner, B. At Risk: Natural Hazards, People's Vulnerability, and Disasters; Routledge: London, UK, 1994.

12. Cutter, S.L. Vulnerability to Environmental Hazards. Prog. Hum. Geogr. 1996, 20, 529-539. 
13. Adger, W.N.; Kelly, P.M. Social Vulnerability to Climate Change and the Architecture of Entitlements. Mitig. Adapt. Strateg. Glob. Change 1999, 4, 253-366.

14. Wilhite, D.A.; Hayes, M.J.; Knutson, C.L. Drought Preparedness Planning: Building Institutional Capacity. In Drought and Water Crisis: Science, Technology, and Management Issues; Wilhite, D.A., Ed.; Taylor \& Francis: Boca Raton, FL, USA, 2005; p. 94.

15. Preparing for Drought in the 21st Century; National Drought Policy Commission: Washington, DC, USA, 2000.

16. Wilhite, D.A.; Glantz, M.H. Understanding the Drought Phenomenon: The Role of Definitions. Water Int'l. 1985, 10, 111-120.

17. Heim, R.R., Jr. A Review of Twentieth-Century Drought Indices Used in the United States. Bull. Am. Meteor. Soc. 2002, 83, 1149-1165.

18. Steinemann, A.C.; Hayes, M.H.; Cavalcanti, L.F.N. Drought Indicators and Triggers. In Drought and Water Crisis: Science, Technology, and Management Issues; Wilhite, D.A., Ed.; Taylor \& Francis: Boca Raton, FL, USA, 2005; pp. 72-85.

19. Vickers, A. Managing Demand: Water Conservation as a Drought Mitigation Tool. In Drought and Water Crisis: Science, Technology, and Management Issues; Wilhite, D.A., Ed.; Taylor \& Francis: Boca Raton, FL, USA, 2005; pp. 173-190.

20. Oweis, T.Y. The Role of Water Harvesting and Supplemental Irrigation in Coping with Water Scarcity and Drought in the Dry Areas. In Drought and Water Crisis: Science, Technology, and Management Issues; Wilhite, D.A., Ed.; Taylor \& Francis: Boca Raton, FL, USA, 2005; pp. 191-213.

21. Dellapenna, J.W. Climate Disruption, the Washington Consensus, and Water Law Reform. Temp. L. Rev. 2008, 81, 383-428.

22. Clausen, T.J.; Bjerg, C. The Blue Revolution: Adapting to Climate Change; Copenhagen Climate Council: Copenhagen, Denmark, 2010; Thought Leadership Series \#6.

23. The Future of the Great Plains; U.S. President's Great Plains Committee: Washington, DC, USA, 1936.

24. Johnson, V. Heaven's Tableland, the Dust Bowl Story; Farrar, Straus \& Co.: New York, NY, USA, 1947.

25. Hoyt, J.C. Drought of 1936, with Discussion on the Significance of Drought in Relation to Climate; U.S. Department of the Interior, Geological Survey: Washington, DC, USA, 1938; Water-Supply Paper 820.

26. Opie, J. Moral Geography in High Plains History. Geogr. Rev. 1999, 88, 241-258.

27. Popper, D.E.; Popper, F.J. The Great Plains: From Dust to Dust. Planning 1987, December, 12-17.

28. Woodhouse, C.A.; Lukas, J.J.; Brown, P.M. Drought in the Western Great Plains, 1845-56, Impacts and Implications. Bull. Amer. Meteor. Soc. 2002, 83, 1485-1493.

29. Riebsame, W.E. Sustainability of the Great Plains in an Uncertain Climate. Great Plains Res. 2000, 1, 133-151.

30. Wilhite, D.A.; Botterill, L.; Monnik, K. National Drought Policy: Lessons Learned from Australia, South Africa, and the United States. In Drought and Water Crisis: Science, Technology, and Management Issues; Wilhite, D.A., Ed.; Taylor \& Francis: Boca Raton, FL, USA, 2005; pp. 138-166. 
31. Wilhite, D.A.; Rosenberg, N.R.; Glantz, M.H. Government Response to Drought in the United States, Lessons from the Mid-1970s; Final Report to the Climate Dynamics Program, National Science Foundation: Washington, DC, USA, 1984.

32. Water Resources: Federal Efforts to Monitor and Coordinate Responses to Drought; U.S. General Accounting Office: Washington, DC, USA, 1993; GAO/RCED-93-116.

33. Dyson, L.K. History of Federal Drought Relief Programs; U.S. Department of Agriculture, Economic Research Service: Washington, DC, USA, 1988; ERS Staff Report No. AgES880914.

34. Eubanks, W.S., II. The Sustainable Farm Bill: A Proposal for Permanent Environmental Change. Envtl. L. Rptr. News Anal. 2009, 39, 10493-10506.

35. Keeney, D.; Kemp, L. A New Agricultural Policy for the United States. In Proceedings of the NATO Advanced Research Workshop on Biodiversity Conservation and Rural Sustainability, Krakow, Poland, November 2002.

36. Global Climate Change Impacts in the United States; Karl, T.R., Melillo, J.M., Peterson, T.C., Eds.; Cambridge University Press: New York, NY, USA, 2009.

37. Kromm, D.E.; White, S.E. Conserving Water in the High Plains; Kansas State University: Manhattan, KS, USA, 1990.

38. McGuire, V.L. Water-Level Changes in the High Plains Aquifer, Predevelopment to 2001, 1999 to 2000, and 2000 to 2001, U.S. Geological Survey: Washington, DC, USA, 2003; USGS Fact Sheet FS-078-03.

39. Glennon, R. Water Follies: Groundwater Pumping and the Fate of America's Fresh Waters; Island Press: Washington, DC, USA, 2002.

40. Davidson, J.H. The Federal Farm Bill and the Environment. Nat. Resour. Envt. 2003, 18, 3-39.

41. Angelo, M.J. Corn, Carbon, and Conservation: Rethinking U.S. Agricultural Policy in a Changing Global Environment. Geo. Mason L. Rev. 2010, 17, 593-660.

42. Ray, D.E.; de la Torre Ugarte, D.G.; Tiller, K.J. Rethinking U.S. Agriculture Policy: Changing Course to Secure Farmer Livelihoods Worldwide; University of Tennessee: Knoxville, TN, USA, 2003.

43. Gleick, P.H.; Nash, L. The Societal and Environmental Costs of the Continuing California Drought; Pacific Institute for Studies in Development, Environment, and Security: Berkeley, CA, USA, 1991.

44. Adler, R.W. Restoring Colorado River Ecosystems: A Troubled Sense of Immensity; Island Press: Washington, DC, USA, 2007.

45. Israel, M.; Lund, J.R. Recent California Water Transfers: Implications for Water Management. Nat. Resour. J. 1995, 35, 1-28.

46. O'Brien, K.M.; Gunning, R.R. Water Marketing in California Revisited: The Legacy of the 1987-92 Drought. Pac. L. J. 1994, 25, 1053-1080.

47. National Study of Water Management during Drought; The Report to the U.S .Congress; U.S. Army Corps of Engineers: Washington, DC, USA, 1995; p. 14.

48. Tackling the Ravages of Drought; Government of Ethiopia: Addis Abba, Ethiopia, 1985.

49. Devastating Drought in Kenya: Environmental Impacts and Responses; United Nations Environment Programme and Government of Kenya: Nairobi, Kenya, 2000. 
50. World Disasters Report 2009, Focus on Early Warning, Early Action; International Federation of Red Cross and Red Crescent Societies: Geneva, Switzerland, 2009.

51. Adler, R.W. Climate Change and the Hegemony of State Water Law. Stan. Envtl. L. J. 2010, 29, 1-61.

52. Mumme, S.P. Managing Acute Water Scarcity on the U.S.-Mexico Border: Institutional Issues Raised by the 1990s Drought. Nat. Resour. J. 1999, 39, 149-164.

53. Federal Response to the 1976-77 Drought: What Should Be Done Next? Comptroller General of the United States, General Accounting Office: Washington, DC, USA, 1979.

54. Trelease, F.J. Climatic Change and Water Law. In Climate, Climatic Change, and Water Supply; National Academy of Sciences: Washington, DC, USA, 1977.

55. Neuman, J.C. Drought Proofing Water Law. U. Denver L. Rev. 2003, 7, 92-108.

56. Kassen, M. Statutory Expansion of State Agencies' Authority to Administer and Develop Water Resources in Response to Colorado's Drought. U. Denver L. Rev. 2003, 7, 48-85.

57. Neuman, J.C. Beneficial Use, Waste and Forfeiture: The Inefficient Search for Efficiency in Western Water Use. Envtl. L. 1998, 28, 919-990.

58. Dellapenna, J.W. The Law of Water Allocation in the Southeastern States at the Opening of the Twenty-First Century. U. Ark. Little Rock L. Rev. 2002, 25, 14-16.

59. Milly, P.C.D.; Betancourt, J.; Falkenmark, M.; Hirsch, R.M.; Kundzewicz, Z.W.; Lettenmaier, D.P.; Stouffer, R.J. Stationarity is Dead: Whiter Water Management? Science 2008, 319, 573-574.

60. Benson, R.D. Deflating the Deference Myth, National Interests vs. State Authority under Federal Laws Affecting Water Use. Utah L. Rev. 2006, 2006, 241-316.

61. Getches, D.H. The Metamorphosis of Western Water Policy: Have Federal Laws and Local Decisions Eclipsed the State Role? Stan. Envtl. L. J. 2001, 20, 3-72.

(C) 2010 by the authors; licensee MDPI, Basel, Switzerland. This article is an Open Access article distributed under the terms and conditions of the Creative Commons Attribution license (http://creativecommons.org/licenses/by/3.0/). 